\title{
HER3 over-expression and overall survival in gastrointestinal cancers
}

\author{
Yadong Wang1,2, Haiyan Yang ${ }^{3}$, Guangcai Duan² \\ ${ }^{1}$ Department of Toxicology, Henan Center for Disease Control and Prevention, Zhengzhou 450016, China \\ ${ }^{2}$ Henan Collaborative Innovation Center of Molecular Diagnosis and Laboratory Medicine, Xinxiang Medical University, \\ Xinxiang 453003, China \\ ${ }^{3}$ Department of Epidemiology, School of Public Health, Zhengzhou University, Zhengzhou 450001, China \\ Correspondence to: \\ Yadong Wang, e-mail: wangyd76@163.com, e-mail: wangyd76@yahoo.com,e-mail: wangyd76@126.com \\ Keywords: HER3, gastrointestinal cancers, overall survival \\ Received: August 18, 2015 \\ Accepted: October 05, 2015 \\ Published: October 17, 2015
}

\section{ABSTRACT}

Published studies on the association between human epidermal factor receptor 3 (HER3) expression and overall survival (OS) in gastrointestinal cancers have yielded conflicting results. The aim of this study was to explore the association of HER3 over-expression with OS in gastrointestinal cancers. A systematic search was performed through Medline/PubMed, Embase, Science Direct and Elsevier. The summary odds ratio (OR) with $95 \%$ confidence interval (CI) was calculated to estimate the strength of the association. Overall, we observed that HER3 over-expression was associated with worse OS at five years (OR $=1.38,95 \%$ CI: 1.04-1.82); however, HER3 over-expression was not associated with worse OS at three years $(O R=1.33,95 \% \mathrm{CI}$ : 0.97-1.84). The cumulative meta-analysis showed similar results. In subgroup analyses by tumor type, HER3 over-expression in gastric cancers was associated with worse OS at both three years $(O R=1.69$, 95\% CI: 1.28-2.25) and five years ( $O R=1.74,95 \% \mathrm{CI}: 1.26-2.41)$. In conclusion, our results suggest that HER3 over-expression may be associated with worse overall survival in gastric cancers. Well-designed studies with a large sample size are required to further confirm our findings.

\section{INTRODUCTION}

Gastrointestinal cancers are a group of highly aggressive malignancies (primarily including gastric carcinoma and colorectal cancer) that constitute a major public health problem worldwide. In 2015 in the United States of America alone, 291,000 new cases are estimated to be diagnosed, and approximately 149,000 patients will die from gastrointestinal cancers [1]. However, the combination of surgery, radiotherapy and chemotherapy remains the standard treatment for gastrointestinal cancer cases, but not all patients derive a benefit from it. Therefore, it is of great clinical value to identify applicable prognostic biomarkers that may not only improve a poor prognosis but also provide novel therapeutic targets.

HER3 (ErbB3) is a member of the human epidermal growth factor receptor (EGFR) family of receptor tyrosine kinases, which consists of four members: HER1/ErbB1, HER2/ErbB2, HER3/ErbB3 and HER4/ ErbB4 [2]. Among the ErbB family, HER3 is a unique member because it lacks intrinsic tyrosine kinase activity and can't form a homodimer; Thus, HER3 forms heterodimers with other members of the ErbB family to carry out its role in signal transduction [3]. HER 3 could effectively couple to the PI3K/AKT pathway, thereby controlling different biological outcomes, including cell proliferation, motility and cell survival [4]. Studies have shown that HER3 plays a key role in the pathogenesis of various human solid tumors [5]. The overexpression of HER 3 has been illustrated in various cancers, including stomach cancer and colorectal cancer [6]. Ciardiello et al. reported that HER3 mRNA was detected in $55 \%$ of primary or metastatic human colorectal carcinomas but in only $22 \%$ of normal colon mucosa 
and $32 \%$ of normal liver samples [7]. Zhang et al.'s study showed that HER3 over-expression was detected in $14(13.7 \%)$ of 102 gastric cancer patients and in $2(2.0 \%)$ of a non-tumorous group of 102 specimens (13.7\% vs. $2.0 \%, P<0.01$ ) [8]. Wu et al.'s study showed that HER3 over-expression was significantly increased in human gastric cancer compared with adjacent normal gastric tissues, as observed by both quantitative real-time reverse transcription-polymerase chain reaction (RT-PCR) and immunohistochemistry (IHC) [9].

The prognostic value and association with clinicopathologic parameters of HER3 expression have recently been investigated in a large series of patients with gastrointestinal cancers [3, 4, 9-17]. However, the results remain inconsistent and conflictive. To address this issue, we performed a meta-analysis to evaluate the potential role of HER3 in relation to overall survival in gastrointestinal cancers.

\section{RESULTS}

\section{Study description}

Among eleven studies, five evaluated colorectal cancer and six evaluated gastric cancer. A total of 1,963 patients was included in this study. All eleven studies reported data that allowed calculation of the overall survival at three years. Ten studies reported data that allowed calculation of the overall survival at five years.

\section{Test of heterogeneity}

Heterogeneity was analyzed for the eleven eligible studies. Our results indicated the presence of heterogeneity in all analyses (Table 1). Therefore, we calculated the pooled ORs for the analyses using a random-effects model.

Table 1: Summary odds ratio of the association between HER3 over-expression and overall survival (OS) in gastrointestinal cancers

\begin{tabular}{|c|c|c|c|c|c|c|c|c|c|c|c|}
\hline \multirow[t]{2}{*}{ Studies } & \multirow[t]{2}{*}{$\begin{array}{l}\text { Number } \\
\text { of studies }\end{array}$} & \multicolumn{2}{|c|}{$\begin{array}{c}\text { Heterogeneity } \\
\text { test }\end{array}$} & \multirow[t]{2}{*}{$\begin{array}{c}\text { Analysis } \\
\text { model }\end{array}$} & \multirow[t]{2}{*}{ OR $(95 \%$ CI $)$} & \multicolumn{2}{|c|}{$\begin{array}{c}\text { Hypothesis } \\
\text { test }\end{array}$} & \multicolumn{2}{|c|}{ Begg's test } & \multicolumn{2}{|c|}{ Egger's test } \\
\hline & & $Q$ & $P$ & & & $Z$ & $P$ & $Z$ & $P$ & $t$ & $P$ \\
\hline \multicolumn{12}{|l|}{ Overall } \\
\hline 3-year OS & 11 & 40.12 & 0.000 & $\begin{array}{l}\text { Random- } \\
\text { effects } \\
\text { model }\end{array}$ & $1.33(0.97-1.84)$ & 1.74 & 0.081 & 0.31 & 0.755 & 0.59 & 0.572 \\
\hline 5-year OS & 10 & 41.72 & 0.000 & $\begin{array}{l}\text { Random- } \\
\text { effects } \\
\text { model }\end{array}$ & $1.38(1.04-1.82)$ & 2.26 & 0.024 & 1.25 & 0.210 & 0.96 & 0.364 \\
\hline \multicolumn{12}{|l|}{$\begin{array}{l}\text { Gastric } \\
\text { cancer }\end{array}$} \\
\hline 3-year OS & 6 & 11.40 & 0.044 & $\begin{array}{l}\text { Random- } \\
\text { effects } \\
\text { model }\end{array}$ & $1.69(1.28-2.25)$ & 3.66 & 0.000 & 0.38 & 0.707 & 1.18 & 0.302 \\
\hline 5-year OS & 5 & 15.67 & 0.003 & $\begin{array}{l}\text { Random- } \\
\text { effects } \\
\text { model }\end{array}$ & $1.74(1.26-2.41)$ & 3.32 & 0.001 & 2.20 & 0.027 & 7.28 & 0.005 \\
\hline \multicolumn{12}{|l|}{$\begin{array}{l}\text { Colorectal } \\
\text { cancer }\end{array}$} \\
\hline 3-year OS & 5 & 12.34 & 0.015 & $\begin{array}{l}\text { Random- } \\
\text { effects } \\
\text { model }\end{array}$ & $0.84(0.48-1.47)$ & 0.62 & 0.536 & 0.73 & 0.462 & 0.46 & 0.679 \\
\hline 5-year OS & 5 & 17.38 & 0.002 & $\begin{array}{l}\text { Random- } \\
\text { effects } \\
\text { model }\end{array}$ & $1.05(0.67-1.65)$ & 0.20 & 0.840 & 0.73 & 0.462 & 0.57 & 0.608 \\
\hline
\end{tabular}




\section{Quantitative data synthesis}

Table 1 lists the summary ORs of the association between HER3 over-expression and overall survival in gastrointestinal cancers. Overall, HER3 overexpression was significantly associated with worse OS at five years (OR $=1.38,95 \%$ CI: 1.04-1.82) (Fig. 1a). However, we did not observe an association between
HER3 over-expression and worse OS at three years $(\mathrm{OR}=1.33$, 95\% CI: 0.97-1.84) (Fig. 1b). In subgroup analyses by tumor type, HER3 over-expression in gastric cancers was associated with worse OS at both three years $(\mathrm{OR}=1.69,95 \% \mathrm{CI}: 1.28-2.25)$ and five years $(\mathrm{OR}=1.74$, 95\% CI: 1.26-2.41) (Table 1). However, we did not observe an association between HER3 over-expression and overall survival at three years and five years in colorectal

a

\begin{tabular}{|c|c|c|}
\hline Study- & $\begin{array}{l}\text { Risk ratio } \\
(95 \% \mathrm{Cl})\end{array}$ & $\%$ Weight \\
\hline Kountourakis 2006 & $1.09(0.69,1.72)$ & 10.1 \\
\hline Baiocchi 2009 & $0.53(0.33,0.85)$ & 10.0 \\
\hline Hay ashi 2008 & $3.25(1.73,6.11)$ & 8.1 \\
\hline Beji 2012 & $-3.76(1.25,11.30)$ & 4.4 \\
\hline Begnami 2011 & $1.27(1.02,1.57)$ & 13.0 \\
\hline Wu 2014 & $1.80(1.20,2.71)$ & 10.8 \\
\hline Seo 2015 & $0.80(0.55,1.17)$ & 11.1 \\
\hline Ledel 2014 & $1.39(0.95,2.03)$ & 11.1 \\
\hline He 2015 & $1.31(0.99,1.72)$ & 12.4 \\
\hline Ema 2014 & $2.52(1.44,4.42)$ & 8.9 \\
\hline Ov erall $(95 \% \mathrm{Cl})$ & $1.38(1.04,1.82)$ & \\
\hline
\end{tabular}

b

\begin{tabular}{|c|c|c|}
\hline Study- & $\begin{array}{l}\text { Risk ratio } \\
(95 \% \mathrm{Cl})\end{array}$ & $\%$ Weight \\
\hline Kountourakis 2006 & $0.54(0.14,2.14)$ & 4.0 \\
\hline Hay ashi 2008 & $5.57(2.09,14.85)$ & 6.1 \\
\hline Baiocchi 2009 & $0.47(0.25,0.85)$ & 9.5 \\
\hline Begnami 2011 & $1.54(1.18,2.01)$ & 12.9 \\
\hline Beji 2012 & $-7.17(1.01,50.89)$ & 2.3 \\
\hline Wu 2014 & $1.84(1.10,3.09)$ & 10.4 \\
\hline Ledel 2014 & $1.22(0.77,1.94)$ & 11.0 \\
\hline Ema 2014 & $2.11(1.15,3.88)$ & 9.4 \\
\hline Tang 2015 & $1.06(0.68,1.66)$ & 11.1 \\
\hline Seo 2015 & $0.69(0.45,1.08)$ & 11.2 \\
\hline He 2015 & $1.59(1.14,2.24)$ & 12.2 \\
\hline Overall $(95 \% \mathrm{Cl})$ & $1.33(0.97,1.84)$ & \\
\hline
\end{tabular}

Figure 1: Forest plot of the odds ratio of the association between HER3 over-expression and overall survival at five years a. and three years $\mathbf{b}$. 
cancers; the summary ORs were 0.84 (95\% CI: 0.48-1.47) and 1.05 (95\% CI: 0.67-1.65), respectively (Table 1).

The cumulative meta-analysis accumulated studies according to publication year and indicated that there was a significant association between HER3 over-expression and overall survival at five years among the total studies, and the cumulative OR was 1.82 (95\% CI: 1.11-2.99)
(Fig. 2a). Similarly, we did not observe a significant association between HER3 over-expression and overall survival at three years among the total studies, and the cumulative OR was 1.62 (95\% CI: 0.98-2.68) (Fig. 2b). The sensitivity analysis showed that the results were robust and were not influenced by any single study (Figs. 3a and 3b).

a

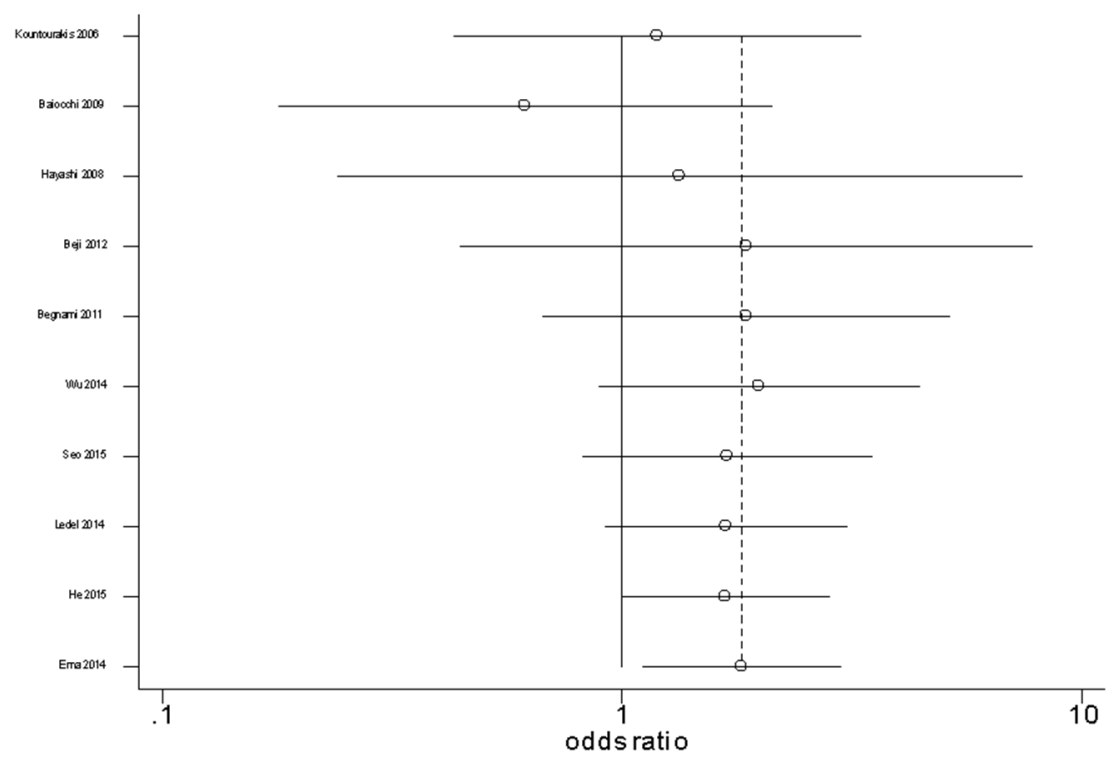

b

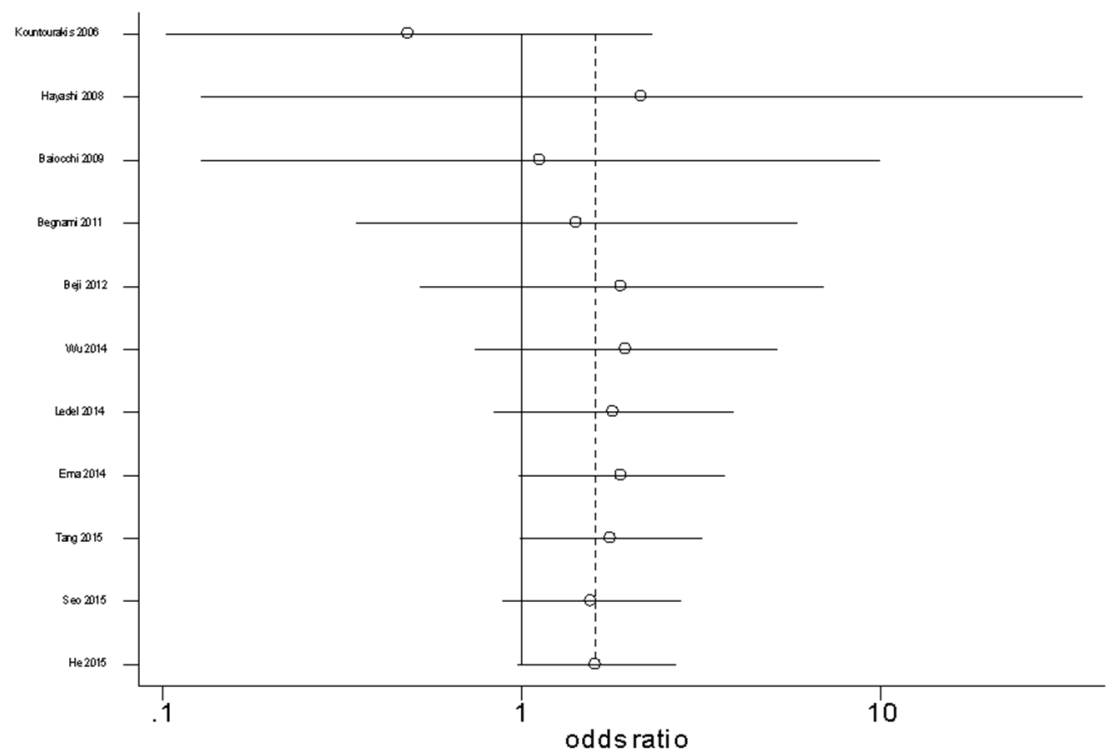

Figure 2: Forest plot of the cumulative odds ratio of the association between HER3 over-expression and overall survival at five years a. and three years $\mathbf{b}$. 


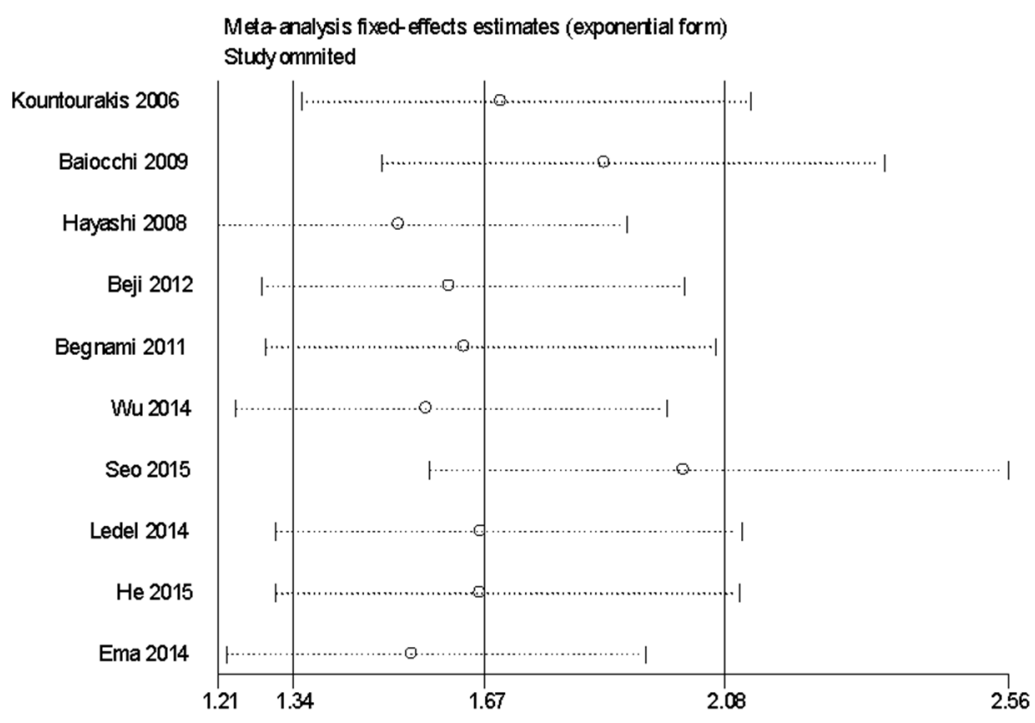

b

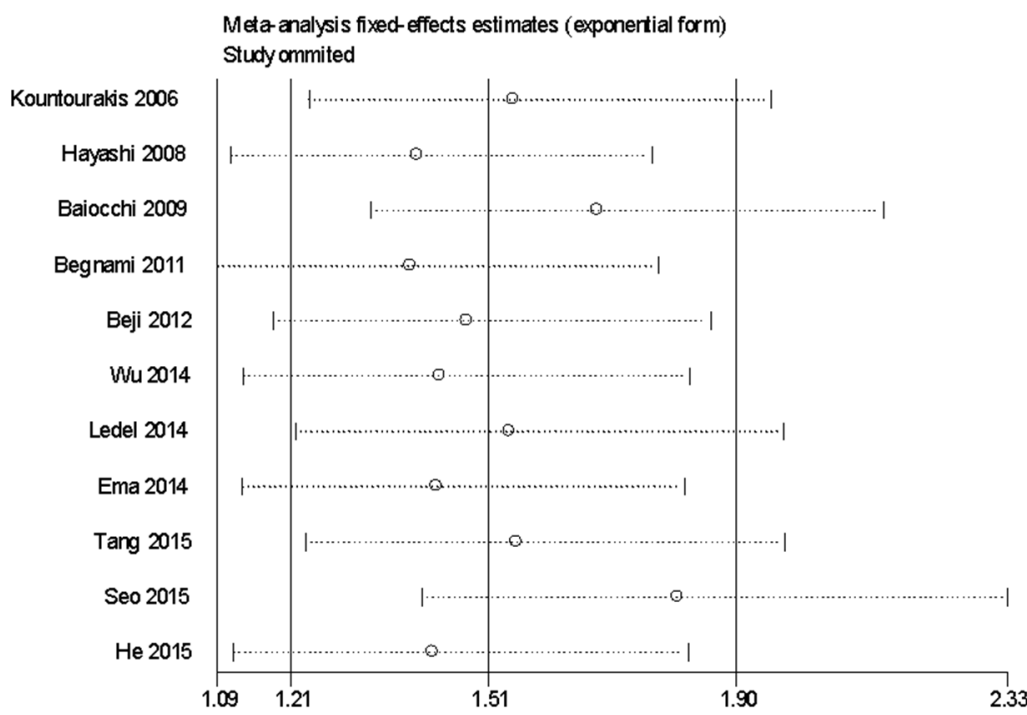

Figure 3: Sensitivity analysis of the association between HER3 over-expression and overall survival at five years a. and three years $\mathbf{b}$.

\section{Bias diagnosis}

The shape of the funnel plots did not reveal any evidence of obvious asymmetry among the overall analysis (Figs. 4a and $4 \mathrm{~b}$ ), suggesting that there was no potential publication bias. Begg's test and Egger's test showed that there was no obvious publication bias in this study, except for the subgroup analysis of gastric cancers at five years overall survival, since the $P$ value was 0.027 at Begg's test and 0.005 at Egger's test, respectively (Table 1).

\section{DISCUSSION}

The HER3 gene is mapped to human chromosome 12q13 and encodes a 160-KDa transmembrane glycoprotein. HER3 has no functional kinase domain and requires dimerization with another receptor to activate downstream signal transduction pathways [10]. It plays an important role in cell proliferation and survival. Over-expression of HER3 has been reported in primary cancers and in cultured cells, including colon cancer and stomach cancer [6]. In this 


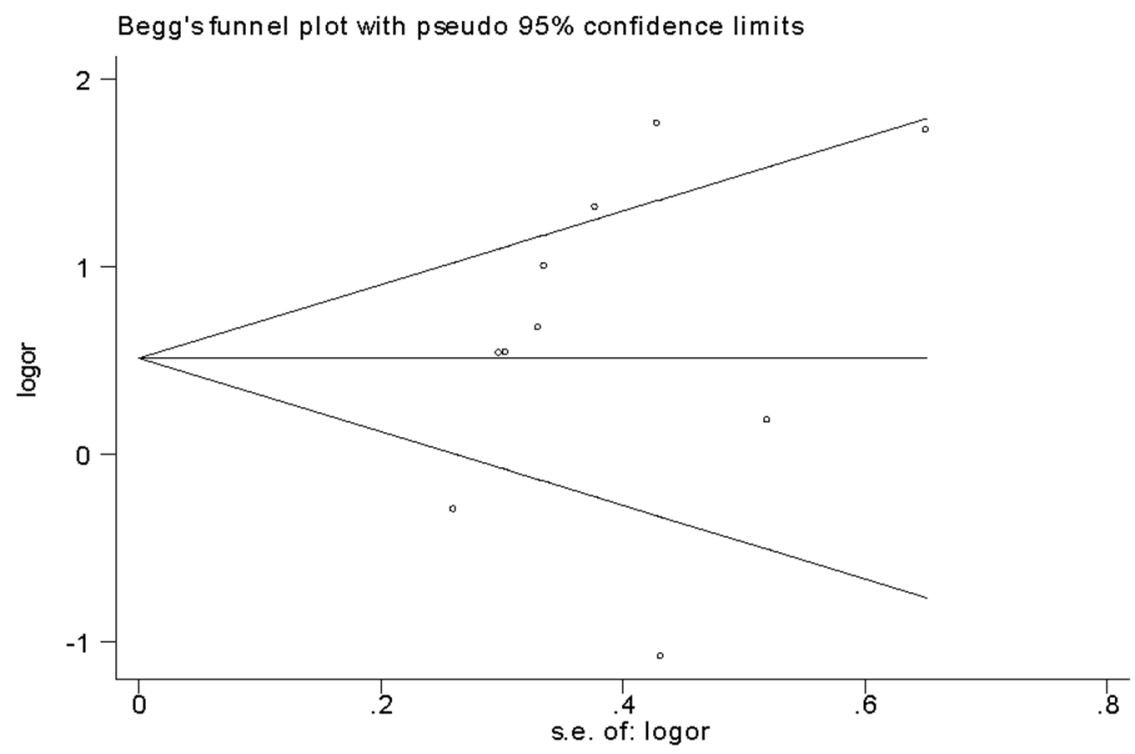

$\mathrm{b}$

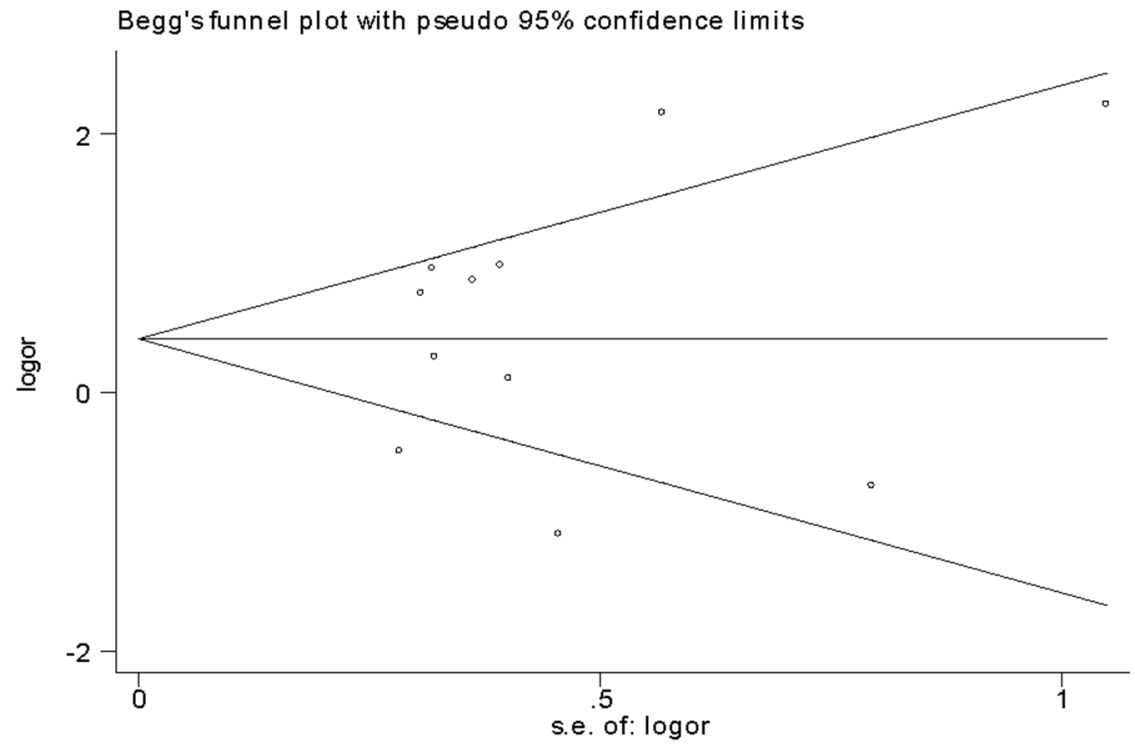

Figure 4: Funnel plot analysis to detect publication bias for the association between HER3 over-expression and overall survival at five years a. and three years $b$.

study, we conducted a meta-analysis of the published data concerning HER3 expression in gastrointestinal cancers and its relationship with overall survival, as determined through studies that detected HER3 by IHC. Our results indicated that HER3 over-expression was significantly associated with worse overall survival in gastrointestinal cancers at five years. Further cumulative meta-analysis demonstrated similar results. In the subgroup analysis stratified by tumor type, over-expression of HER3 was significantly associated with worse overall survival in gastric cancers at both three years and five years.

To the best of our knowledge, only one metaanalysis has reported an association between HER3 over-expression and survival in solid tumors [18]. The authors found that HER3 over-expression was associated with worse survival at both three years and five years in gastric cancers, but their study was based on only two studies with 325 patients, resulting in the 
enrolled studies and sample size being relatively small. Our results are consistent with those reported by Ocana et al. [18]. However, compared with the Ocana et al.'s study [18], our study has several advantages. First, we amplified the number of studies to six and enlarged the sample size to 1,038 , making our findings more powerful and substantial. Second, a cumulative metaanalysis was performed to consolidate our findings. Third, a sensitivity analysis was conducted to check the effects of an individual study on the summary odds ratio. In addition, publication bias was assessed using the funnel plot, Begg's test and Egger's test. Ocana et al.'s study [18] and ours did not observe a significant association between HER3 over-expression and worse overall survival at three years and five years in colorectal cancers.

Although the underlying mechanisms involved in the association between HER3 over-expression and gastrointestinal cancers remain uncertain, several studies may allude the critical involvement of HER3 in the progression of gastrointestinal cancers to some extent. Lee et al. reported that HER3 knockdown induced cell cycle arrest and activation of Bak- and Bax-dependent apoptosis in colon cancer cells [19]. Beji et al.'s study showed that HER3 knockdown by RNA interference and anti-HER3 monoclonal antibody resulted in the inhibition of cell proliferation, migration and invasion, G2-M cell cycle arrest, and the induction of apoptosis in colon cancer cell lines [4]. Gaborit et al. reported that HER3 monoclonal antibody could inhibit the growth of gastric cancer cells (N87) in vitro and in animals [20]. Wu et al.'s study showed that knockdown of HER3 in the human gastric cancer cell line could inhibit cell proliferation and tumor growth both in vitro and in vivo by the inactivation of AKT [9].

Recent identification of several HER3 oncogenic mutations in colon and gastric cancers elucidated the role of HER3 in cancer development [6]. Jeong et al.'s study reported sporadic protein-altering HER3 mutations in $1 \%$ of colon cancers $(1 / 100)$ [21]. Wang et al. observed that frequent mutations in the HER3 gene occurred in $10 \%$ of gastric cancers (2/22) [22]. A recent large-scale genomics study reported HER3 mutations in $7 \%$ of colon cancers (14/212) [23]. Jaiswal et al. reported the identification of HER3 somatic mutations in $11 \%$ of colon cancers $(11 / 100)$ and $12 \%$ of gastric cancers (11/92). Jaiswal et al. also found that HER3 mutants co-expressed with HER2 promoted anchorageindependent growth of immortalized mouse colonic epithelial (IMCE) cells compared with HER3-wild type or the mutants when expressed on their own. Consistent with their ability to support anchorage-independent growth, IMCE cells co-expressing HER3 mutants along with HER2 showed an increase in tumor growth compared with HER3-wild type or HER2 alone or HER3-wild type and HER2 combined.

There are several potential limitations inherent to this meta-analysis. First, this is a literature-based analysis, and only published articles were included in this study; thus, publication bias may exist in this study. To address this issue, Egger's test and Begg's test were applied. Second, this study was based on population-level data rather than individual patient level data. Several confounders were not controlled, and multivariate analyses could not be conducted. Third, there is substantial heterogeneity in all of the analyses, which may not be completely interpreted by our use of the random-effects model. Fourth, the proportion of three years and five years survival was extracted directly from Kaplan-Meier curves, which may slightly deviate from the raw data.

\section{MATERIALS AND METHODS}

\section{Literature and methods}

A systematic search was performed using the Medline/PubMed, Embase, Science Direct and Elsevier databases with a combination of the terms: "HER3" or "ErbB3" or "human epidermal factor receptor 3" and "digestive tract cancer" or "gastrointestinal cancer" or "gastric cancer" or "colorectal cancer". The ending date was July, 31, 2015.

The selection criteria included (1) the measurement of HER3 by immunohistochemistry; (2) the availability of survival data at three years and/or five years; and (3) the reporting of gastrointestinal cancers. Accordingly, papers without complete data, reviews and overlapping or duplicate papers were excluded.

In total, thirteen published studies that reported an association between HER3 expression and overall survival in gastrointestinal cancers were identified. We reviewed all of these papers in accordance with the criteria defined above and excluded two papers [24, 25] without complete data. Therefore, eleven eligible studies were included in this study. The flow diagram of the selection process is shown in Fig. 5.

\section{Data extraction}

Data were extracted and tabulated by two of the authors, and inputted into an electronic database independently. The following details were extracted: authors' name, year of publication, tumor type, number of patients, percentage of HER3 over-expression and cutoff of over-expression. The proportion of patients surviving to three and five years was extracted directly 


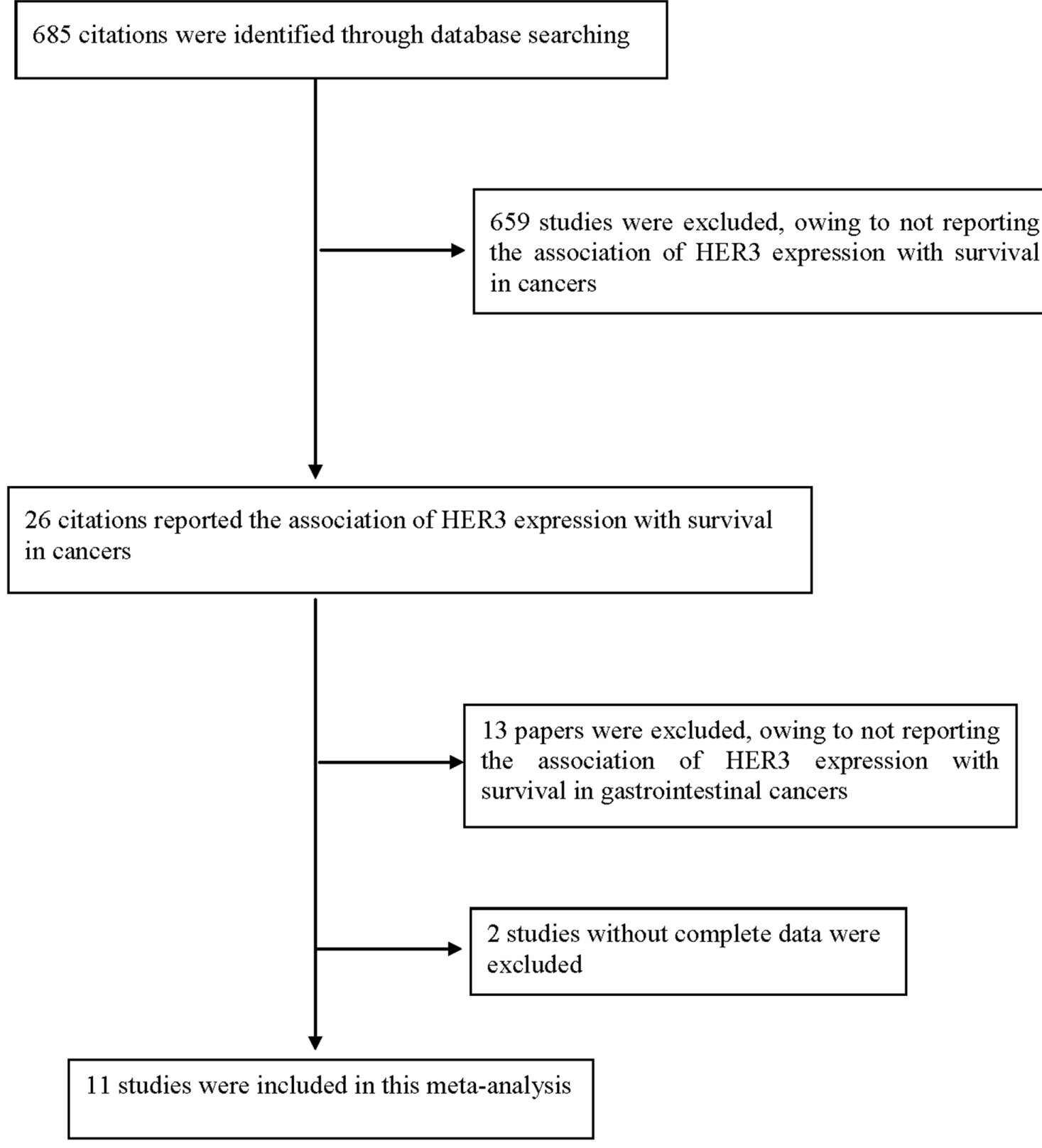

Figure 5: Flow diagram of the selection process.

from the Kaplan-Meier curves. The quality of the studies was evaluated according to the Newcastle-Ottawa quality assessment scale $[26,27]$. The main characteristics of individual studies are summarized in Table 2.

\section{Quantitative data synthesis}

The heterogeneity among the studies was evaluated by the Cochrane Q statistics test. The random-effects model and fixed-effects model were used to estimate the summary ORs [28]. The fixed-effects model was used if the effects were assumed to be homogeneous; otherwise, the random-effects model was used. First, the publication bias was visually checked using funnel plots, and Begg's test and Egger's test were then used to further diagnose the publication bias $[29,30]$. A sensitivity analysis was performed by deleting one study each time.

All of the statistical analyses were performed using STATA10.0 software package (Stata Corporation, College Station, TX, USA). All of the tests were two-sided, and a $P$ value less than 0.05 was considered to be statistically significant. 
Table 2: Evaluation of HER3 by immunohistochemistry in the selected studies

\begin{tabular}{|c|c|c|c|c|c|c|}
\hline Author & Year & $\begin{array}{l}\text { Tumor } \\
\text { Type }\end{array}$ & $\begin{array}{l}\text { Number } \\
\text { of } \\
\text { patients }\end{array}$ & $\begin{array}{l}\text { Percentage } \\
\text { of HER3 } \\
\text { over- } \\
\text { expression } \\
(\%)\end{array}$ & Cutoff for HER3 over-expression & $\begin{array}{l}\text { Quality } \\
\text { score }\end{array}$ \\
\hline $\begin{array}{l}\text { Kountourakis } \\
{[10]}\end{array}$ & 2006 & Colorectal & 106 & $17.0 \%$ & $\begin{array}{l}\text { Positive: Membranous staining: }>1 \% \text { of tumor } \\
\text { cells stained. Cytoplasmic staining: } 2+: \text { moderate } \\
\text { immunostaining in }>10 \% \text { of tumor cells and } 3+: \\
\text { strong immunostaining in }>10 \% \text { of tumor cells. }\end{array}$ & 6 \\
\hline Hayashi [11] & 2008 & Gastric & 134 & $59.0 \%$ & $\begin{array}{l}\text { Positive: } 2+=\text { moderate staining, and } 3+=\text { strong } \\
\text { staining. }\end{array}$ & 7 \\
\hline Baiocchi [12] & 2009 & Colorectal & 109 & $69.7 \%$ & $\begin{array}{l}\text { Cytoplasmic staining was scored as " } 0 \text { " with no } \\
\text { staining or weak staining in }<10 \% \text { of tumor cells; } \\
\text { membranous staining: " } 0 \text { " when there was no } \\
\text { staining at all or membrane staining }<10 \% \text { of tumor } \\
\text { cells; " } 1+\text { " with perceptible membrane staining in } \\
>10 \% \text { tumor cells; " } 2+" \text { with weak-to-moderate } \\
\text { staining of the entire membrane in more than } 10 \% \\
\text { tumor cells; " } 3+" \text { with strong staining of the entire } \\
\text { membrane in }>10 \% \text { tumor cells. }\end{array}$ & 5 \\
\hline Begnami [13] & 2011 & Gastric & 191 & $34.0 \%$ & $\begin{array}{l}\text { Slices with scores of } 8 \text { or higher were classified as } \\
\text { positive, and slices with scores lower than } 8 \text { were } \\
\text { classified as negative. }\end{array}$ & 6 \\
\hline Beji [4] & 2012 & Colorectal & 110 & $74.5 \%$ & $\begin{array}{l}\text { HER3 expression was classified as weak, } \\
\text { intermediate, or strong (analysis compared low vs. } \\
\text { intermediate }+ \text { strong). }\end{array}$ & 6 \\
\hline $\mathrm{Wu}[9]$ & 2014 & Gastric & 161 & $55.9 \%$ & $\begin{array}{l}\text { Scores } 0 \text { and } 1 \text { were considered negative, and scores } \\
2 \text { and } 3 \text { were considered positive for HER } 3 \text {. }\end{array}$ & 6 \\
\hline Ledel [15] & 2014 & Colorectal & 236 & $69.5 \%$ & $\begin{array}{l}\text { The intensity of staining was graded } 0-3 \text {, where } \\
\text { grade } 0-1 \text { was categorized as low, and grade } 2-3 \text { was } \\
\text { categorized as high expression of membranous HER3. }\end{array}$ & 7 \\
\hline Ema [14] & 2014 & Gastric & 167 & $58.7 \%$ & $\begin{array}{l}0=\text { no staining observed in invasive tumor cells, } \\
1+=\text { weak, incomplete membrane staining in } \\
\text { any proportion of invasive tumor cells, or weak, } \\
\text { complete membrane staining in less than } 10 \% \text { of } \\
\text { cells, } 2+=\text { complete membrane staining that is non- } \\
\text { uniform or weak but with obvious circumferential } \\
\text { distribution in at least } 10 \% \text { of cells, or intense } \\
\text { complete membrane staining in } 30 \% \text { or less of } \\
\text { tumor cells, } 3+=\text { uniform intense membrane } \\
\text { staining of more than } 30 \% \text { of invasive tumor cells. }\end{array}$ & 6 \\
\hline Tang [16] & 2015 & Gastric & 114 & $66.7 \%$ & $\begin{array}{l}0, \text { if no staining was observed; } 1+\text {, if more than } \\
10 \% \text { of the tumor cells had weak staining on the } \\
\text { membrane (or cytoplasm for HER } 3 \text { ); } 2+, \text { if more } \\
\text { than } 10 \% \text { of the tumor cells had moderate staining } \\
\text { on the membrane (or cytoplasm for HER } 3 \text { ); and } \\
3+, \text { if more than } 10 \% \text { of the tumor cells had strong } \\
\text { staining on the membrane (or cytoplasm for HER3). }\end{array}$ & 5 \\
\hline
\end{tabular}

(Continued) 


\begin{tabular}{|c|c|c|c|c|c|c|}
\hline Author & Year & $\begin{array}{l}\text { Tumor } \\
\text { Type }\end{array}$ & $\begin{array}{l}\text { Number } \\
\text { of } \\
\text { patients }\end{array}$ & $\begin{array}{l}\text { Percentage } \\
\text { of HER3 } \\
\text { over- } \\
\text { expression } \\
(\%)\end{array}$ & Cutoff for HER3 over-expression & $\begin{array}{l}\text { Quality } \\
\text { score }\end{array}$ \\
\hline Seo [3] & 2015 & Colorectal & 364 & $69.0 \%$ & $\begin{array}{l}0 \text { and } 1+\text { were considered no-over-expression, and } \\
2+\text { and } 3+\text { were considered over-expression. }\end{array}$ & 7 \\
\hline $\mathrm{He}[17]$ & 2015 & Gastric & 271 & $20.7 \%$ & $\begin{array}{l}\text { Immunoreactive results of } 2+\text { or } 3+\text { were considered } \\
\text { to be positive or high expression. By contrast, } 0 \text { or } \\
1+\text { was evaluated as negative or low expression. }\end{array}$ & 7 \\
\hline
\end{tabular}

\section{CONCLUSION}

In summary, this meta-analysis found that HER3 over-expression was associated with worse overall survival at three years and five years in gastric cancers. Studies with a larger sample size are required to further verify our findings.

\section{ACKNOWLEDGMENTS}

This work was supported by a grant from the National Natural Science Foundation of China (No. U1404815).

\section{CONFLICTS OF INTEREST}

The authors declare no conflicts of interest.

\section{REFERENCES}

1. Goel G, Sun W. Advances in the management of gastrointestinal cancers-an upcoming role of immune checkpoint blockade. J Hematol Oncol. 2015; 8:86.

2. Jaiswal BS, Kljavin NM, Stawiski EW, Chan E, Parikh C, Durinck S, et al. Oncogenic ERBB3 mutations in human cancers. Cancer Cell. 2013; 23:603-617.

3. Seo AN, Kwak Y, Kim WH, Kim DW, Kang SB, Choe G, et al. HER3 protein expression in relation to HER2 positivity in patients with primary colorectal cancer: clinical relevance and prognostic value. Virchows Arch. 2015; 466:645-654.

4. Beji A, Horst D, Engel J, Kirchner T, Ullrich A. Toward the prognostic significance and therapeutic potential of HER3 receptor tyrosine kinase in human colon cancer. Clin Cancer Res. 2012; 18:956-968.

5. Hynes NE, Lane HA. ERBB receptors and cancer: the complexity of targeted inhibitors. Nat Rev Cancer. 2005; 5:341-354.

6. Mujoo K, Choi BK, Huang Z, Zhang N, An Z. Regulation of ERBB3/HER3 signaling in cancer. Oncotarget. 2014; 5:10222-10236.
7. Ciardiello F, Kim N, Saeki T, Dono R, Persico MG, Plowman GD, et al. Differential expression of epidermal growth factor-related proteins in human colorectal tumors. Proc Natl Acad Sci U S A. 1991; 88:7792-7796.

8. Zhang XL, Yang YS, Xu DP, Qu JH, Guo MZ, Gong Y, et al. Comparative study on overexpression of HER2/ neu and HER3 in gastric cancer. World J Surg. 2009; 33:2112-2118.

9. Wu X, Chen Y, Li G, Xia L, Gu R, Wen X, et al. Her3 is associated with poor survival of gastric adenocarcinoma: Her3 promotes proliferation, survival and migration of human gastric cancer mediated by PI3K/AKT signaling pathway. Med Oncol. 2014; 31:903.

10. Kountourakis P, Pavlakis K, Psyrri A, Rontogianni D, Xiros N, Patsouris E, et al. Prognostic significance of HER3 and HER4 protein expression in colorectal adenocarcinomas. BMC Cancer. 2006; 6:46.

11. Hayashi M, Inokuchi M, Takagi Y, Yamada H, Kojima K, Kumagai J, et al. High expression of HER3 is associated with a decreased survival in gastric cancer. Clin Cancer Res. 2008; 14:7843-7849.

12. Baiocchi G, Lopes A, Coudry RA, Rossi BM, Soares FA, Aguiar S, et al. ErbB family immunohistochemical expression in colorectal cancer patients with higher risk of recurrence after radical surgery. Int J Colorectal Dis. 2009; 24:1059-1068.

13. Begnami MD, Fukuda E, Fregnani JH, Nonogaki S, Montagnini AL, da Costa WL Jr., et al. Prognostic implications of altered human epidermal growth factor receptors (HERs) in gastric carcinomas: HER2 and HER3 are predictors of poor outcome. J Clin Oncol. 2011; 29:3030-3036.

14. Ema A, Yamashita K, Ushiku H, Kojo K, Minatani N, Kikuchi M, et al. Immunohistochemical analysis of RTKs expression identified HER3 as a prognostic indicator of gastric cancer. Cancer Sci. 2014; 105:1591-1600.

15. Ledel F, Hallstrom M, Ragnhammar P, Ohrling K, Edler D. HER3 expression in patients with primary colorectal cancer and corresponding lymph node metastases related to clinical outcome. Eur J Cancer. 2014; 50:656-662.

16. Tang D, Liu CY, Shen D, Fan S, Su X, Ye P, et al. Assessment and prognostic analysis of EGFR, HER2, and 
HER3 protein expression in surgically resected gastric adenocarcinomas. Onco Targets Ther. 2015; 8:7-14.

17. He XX, Ding L, Lin Y, Shu M, Wen JM, Xue L. Protein expression of HER2, 3, 4 in gastric cancer: correlation with clinical features and survival. J Clin Pathol. 2015; 68:374-380.

18. Ocana A, Vera-Badillo F, Seruga B, Templeton A, Pandiella A, Amir E. HER3 overexpression and survival in solid tumors: a meta-analysis. J Natl Cancer Inst. 2013; 105:266-273.

19. Lee H, Chin H, Kim K, Lee D. ERBB3 knockdown induces cell cycle arrest and activation of Bak and Baxdependent apoptosis in colon cancer cells. Oncotarget. 2014; 5:5138-5152.

20. Gaborit N, Abdul-Hai A, Mancini M, Lindzen M, Lavi S, Leitner $\mathrm{O}$, et al. Examination of HER3 targeting in cancer using monoclonal antibodies. Proc Natl Acad Sci U S A. 2015; 112:839-844.

21. Jeong EG, Soung YH, Lee JW, Lee SH, Nam SW, Lee JY, et al. ERBB3 kinase domain mutations are rare in lung, breast and colon carcinomas. Int J Cancer. 2006; 119:2986-2987.

22. Wang K, Kan J, Yuen ST, Shi ST, Chu KM, Law S, et al. Exome sequencing identifies frequent mutation of ARID1A in molecular subtypes of gastric cancer. Nat Genet. 2011; 43:1219-1223.
23. TCGA Cancer Genome Atlas Network . Comprehensive molecular characterization of human colon and rectal cancer. Nature. 2012; 487:330-337.

24. Jacome AA, Wohnrath DR, Scapulatempo Neto C, Carneseca EC, Serrano SV, Viana LS, et al. Prognostic value of epidermal growth factor receptors in gastric cancer: a survival analysis by Weibull model incorporating longterm survivors. Gastric Cancer. 2014; 17:76-86.

25. Lee J, Jain A, Kim P, Lee T, Kuller A, Princen F, et al. Activated cMET and IGF1R-driven PI3K signaling predicts poor survival in colorectal cancers independent of KRAS mutational status. PLoS One. 2014; 9:e103551.

26. Stang A. Critical evaluation of the Newcastle-Ottawa scale for the assessment of the quality of nonrandomized studies in meta-analyses. Eur J Epidemiol. 2010; 25:603-605.

27. Yildirim M, Kaya V, Demirpence O, Gunduz S, Bozcuk H. Prognostic significance of p53 in gastric cancer: a metaanalysis. Asian Pac J Cancer Prev. 2015; 16:327-332.

28. DerSimonian R, Laird N. Meta-analysis in clinical trials. Control Clin Trials. 1986; 7:177-188.

29. Begg CB, Mazumdar M. Operating characteristics of a rank correlation test for publication bias. Biometrics. 1994; 50:1088-1101.

30. Egger M, Davey Smith G, Schneider M, Minder C. Bias in meta-analysis detected by a simple, graphical test. BMJ. 1997; 315:629-634. 